\title{
Physician-Patient Communication : A Tool for optimum satisfaction
}

\author{
A M Talukder ${ }^{1}$, F Mahejabin ${ }^{2}$, A A Faruk ${ }^{3}$, 0 R Sultan ${ }^{4}$, A Sufian ${ }^{5}$, M A Mannan ${ }^{6}$
}

\section{Introduction}

Communication is an important component of patient care. Having good communication skill is essential for Physician to establish good Physician patient relationship. Effective Physician-patient communication is a central clinical function in building a therapeutic doctor-patient relationship, which is the heart and art of medicine. This is important in the delivery of highquality health care. Much patient dissatisfaction and many complaints are due to breakdown in the doctorpatient relationship. A doctor's communication and interpersonal skills encompass the ability to gather information in order to facilitate accurate diagnosis, counsel appropriately, give therapeutic instructions, and establish caring relationships with patients. ${ }^{1}$ These are the core clinical skills in the practice of medicine, with the ultimate goal of achieving the best outcome and patient satisfaction, which are essential for the effective delivery of health care.

Prof. Dr. Abu Mohammad Talukde Professor

Dept. of Paediatrics

MH Samorita Medical College

${ }^{2}$ Dr. Farzana Mahejabin

Associate Professor

Dept. of Community Medicine

Dhaka Community Medical College

${ }^{3}$ Dr. Abdullah Al-Faruk

Associate Professor of Paed.

Kumudini Women Medical College

${ }^{4}$ Dr. Quazi Rakibus Sultan

Assistant Professor of Dermatology

Dhaka Community Medical College

${ }^{5}$ Dr. Abu Sufian

Junior Consultant of Paed.

Habiganj Sadar Hospital

${ }^{6}$ Dr. Md. Abdul Mannan

Assistant Professor of

Neonatology and Paediatrics

Ad-din Medical College

Correspondence

Prof. Dr. Abu Mohammad Talukder Professor

Dept. of Paediatrics

MH Samorita Medical College
Studies on doctor-patient communication have demonstrated patient discontent even when many doctors considered the communication adequate or even excellent. Doctors tend to overestimate their abilities in communication. Tongue et al reported that $75 \%$ of the orthopedic surgeons surveyed believed that they communicated satisfactorily with their patients, but only $21 \%$ of the patients reported satisfactory communication with their doctors. ${ }^{2}$ Patient surveys have consistently shown that they want better communication with their doctors.

Common expectations patients have for their physicians are:

Primary Expectations : • Clinical Competence

Secondary Expectations : • Professional • Respectful • Polite - Sincere - Interested - Effective Communication SkillsVerbal and Non-Verbal

Behaviors that satisfy these expectations, as well as serve to develop rapport with the patient are : being well groomed, addressing the patient by name, introducing oneself, developing an agenda, avoiding judgmental behaviors, appropriate eye contact/ facial expressions and posture ${ }^{3}$

Tools for Communication Skills on Basic elements for medical interview/interaction with the patient

\section{Initial Encounter}

The First Impression- The most important one that occurs.
The patient, in the first few moments, will decide if he/she will feel comfortable with the doctor and most of this first impression is made not on what the doctor says, but how he/she says it and how he/she interacts with the patient ${ }^{4}$

\begin{tabular}{|l|l|}
\hline $\begin{array}{l}\text { Be Prepared-know } \\
\text { who the patient is } \\
\text { before you walk } \\
\text { through the door }\end{array}$ & $\begin{array}{l}\text { Don't fumble for a name after } \\
\text { you are in the room. Never call a } \\
\text { patient over the pediatric age } \\
\text { group by their first name without } \\
\text { permission, it is disrespectful. }\end{array}$ \\
\hline $\begin{array}{l}\text { Make eye contact } \\
\text { with the patient, } \\
\text { shake hands, and } \\
\text { introduce yourself }\end{array}$ & $\begin{array}{l}\text { Indicate your role to the patient. } \\
\text { You can not assume that the } \\
\text { patient will know who you are. }\end{array}$ \\
\hline $\begin{array}{l}\text { Set the patient at } \\
\text { ease and build } \\
\text { rapport }\end{array}$ & $\begin{array}{l}\text { Most patients will be nervous } \\
\text { when meeting the doctor for the } \\
\text { fist time. If appropriate, you can } \\
\text { consider an initial inquiry into non } \\
\text { medical areas to assist in } \\
\text { developing a relationship with him } \\
\text { as a person. }\end{array}$ \\
\hline Have a seat & $\begin{array}{l}\text { Where you are positioned relative } \\
\text { to the patient is important. It is } \\
\text { intimidating to the patient to } \\
\text { stand over them. The patient } \\
\text { should not have to look up to you } \\
\text { to make eye contact. }\end{array}$ \\
\hline Let the patient tell \\
their story
\end{tabular} $\begin{aligned} & \text { Ask the patient to explain why is } \\
& \text { she/he here. }\end{aligned}$

\section{Conducting the interview}

As the patient explains the chief complaint and the history of the present illness, you can question the patient using the following skills and techniques.

\begin{tabular}{|c|c|}
\hline $\begin{array}{l}\text { Use open-ended } \\
\text { questions }\end{array}$ & $\begin{array}{l}\text { This is done to obtain general information } \\
(\text { "Tell me more about..." "Describe the pain } \\
\text { for me") }\end{array}$ \\
\hline $\begin{array}{l}\text { Direct/closed } \\
\text { ended questions }\end{array}$ & $\begin{array}{l}\text { Used as a follow up of the open-ended } \\
\text { questions ("Did you experience...," Does } \\
\text { the pain go anywhere?") }\end{array}$ \\
\hline $\begin{array}{l}\text { Avoid leading } \\
\text { questions }\end{array}$ & $\begin{array}{l}\text { Leading questions may suggest to the } \\
\text { patient the desired answer }\end{array}$ \\
\hline & $\begin{array}{l}\text { Presenting more than one question is } \\
\text { confusing and inconsiderate }\end{array}$ \\
\hline $\begin{array}{l}\text { Keep the interview } \\
\text { organized and use } \\
\text { transition statements }\end{array}$ & $\begin{array}{l}\text { Try not to jump around from one topic to } \\
\text { another. The patient should be able to } \\
\text { understand what the purpose of any } \\
\text { question would be. }\end{array}$ \\
\hline $\begin{array}{l}\text { Learn about the } \\
\text { patient and his/her } \\
\text { family }\end{array}$ & $\begin{array}{l}\text { Do this formally and informally, during the } \\
\text { course of the interview when discussing } \\
\text { social and family history but also through } \\
\text { an ongoing conversation with the patient }\end{array}$ \\
\hline $\begin{array}{l}\text { ncourage the } \\
\text { atient to ask } \\
\text { juestions }\end{array}$ & $\begin{array}{l}\text { This will further develop trust and enhance } \\
\text { your relationship with the patient }\end{array}$ \\
\hline
\end{tabular}




\section{Responding to the Patient-}

There is an opportunity to provide the patient with empathy, a key component of rapport building. Without empathy, the patient will never develop any trust that you understand and sympathize with their situation. ${ }^{5}$

\begin{tabular}{|l|l|}
\hline $\begin{array}{l}\text { Pay attention to } \\
\text { the clues, both } \\
\text { verbal and non } \\
\text { verbal from the } \\
\text { patient that they may } \\
\text { not be relating to the } \\
\text { problem. }\end{array}$ & $\begin{array}{l}\text { Verbal-It is often difficult for patients to disclose } \\
\text { personal information about themselves or problems } \\
\text { they may be experiencing.Non-Verbal-The } \\
\text { satient's body language may be telling you }\end{array}$ \\
\hline $\begin{array}{l}\text { Avoid judgmental } \\
\text { language or } \\
\text { behaviors }\end{array}$ & $\begin{array}{l}\text { Put aside your own beliefs, values and refrain from } \\
\text { projecting them onto the patient. The medical } \\
\text { problem or issue needs to be understood from } \\
\text { patients perspective. }\end{array}$ \\
\hline Build Partnership & \begin{tabular}{l} 
This entails offering your support. \\
\hline $\begin{array}{l}\text { Provide } \\
\text { Encouragement }\end{array}$
\end{tabular}$\quad \begin{array}{l}\text { Praising patients also strengthens the patient- } \\
\text { doctor relationship. Offer them praise (e.g...."It } \\
\text { sounds like cutting back on smoking has been } \\
\text { difficult for you, but I'm glad to hear you have not } \\
\text { given up trying") }\end{array}$ \\
\hline $\begin{array}{l}\text { Be aware of your } \\
\text { non-verbal cues }\end{array}$ & $\begin{array}{l}\text { Being attentive, making eye contact, and providing } \\
\text { positive cues will encourage the patient to be open } \\
\text { with you. Your body language should show that you } \\
\text { are engaged, do not sit back in the chair, rather } \\
\text { lean forward and pay attention. }\end{array}$ \\
\hline
\end{tabular}

\section{Educating, negotiating and collaborating with the patient}

Once all the information is collected from the history, physical exam, and other testing, it is time to explain to the patient what you believe the problem to be and what the next steps should be. You need to explain this to the patient in a language that they can understand. ${ }^{3}$

\begin{tabular}{|l|l|}
\hline $\begin{array}{l}\text { Avoid the use of } \\
\text { medical jargon or } \\
\text { abbreviations }\end{array}$ & $\begin{array}{l}\text { Unexplained medical jargon can have a } \\
\text { negative effect on the conversation's equilibrium. }\end{array}$ \\
\hline $\begin{array}{l}\text { Ascertain that the } \\
\text { patient understands } \\
\text { the information you } \\
\text { have provided }\end{array}$ & $\begin{array}{l}\text { You can do this by involving them in the conversation, } \\
\text { not just talking with them. Assessing the patient's } \\
\text { understanding can be done in a non-condescending way } \\
\text { by simply asking, "What will you tell your family about } \\
\text { today's visit? }\end{array}$ \\
\hline $\begin{array}{l}\text { Elicit the patient's } \\
\text { feeling or concerns } \\
\text { about the information }\end{array}$ & $\begin{array}{l}\text { (e.g....'What thoughts do you have about this so far?) } \\
\text { and respond appropriately }\end{array}$ \\
\hline $\begin{array}{l}\text { Collaborate with the } \\
\text { patient }\end{array}$ & $\begin{array}{l}\text { Although you can explain your recommendation, do not } \\
\text { assume that the patient will automatically agree with } \\
\text { you. The plan needs to conform to the patient's } \\
\text { understanding, belief system and values }\end{array}$ \\
\hline $\begin{array}{l}\text { Discover potential } \\
\text { barriers }\end{array}$ & $\begin{array}{l}\text { You must be sensitive to the patient's concerns and must } \\
\text { explore any reason why they would not be comfortable } \\
\text { with a given plan (e.g...."What obstacles/factors would } \\
\text { prevent you from being able to comply with this plan?") }\end{array}$ \\
\hline
\end{tabular}

\section{Closing the interview}

At the end of the interview, it is important for you to establish that both you and the patient understand what occurred and what the plan is going to be ${ }^{6}$

\begin{tabular}{|l|l|}
\hline $\begin{array}{l}\text { Summarize the } \\
\text { encounter }\end{array}$ & $\begin{array}{l}\text { Do this for the patient and to get their agreement } \\
\text { of their summary }\end{array}$ \\
\hline $\begin{array}{l}\text { Answer the } \\
\text { patient's questions }\end{array}$ & $\begin{array}{l}\text { The patient should leave knowing that all of their } \\
\text { concerns have been addressed }\end{array}$ \\
\hline $\begin{array}{l}\text { Confirm } \\
\text { partnership }\end{array}$ & $\begin{array}{l}\text { The patient needs to be able to depend on the fact } \\
\text { that you will be there in the future for them. }\end{array}$ \\
\hline $\begin{array}{l}\text { Provide your } \\
\text { initial thoughts }\end{array}$ & $\begin{array}{l}\text { In any given situation, you may need to discuss the } \\
\text { plan with your supervising physician. However, if } \\
\text { appropriate you should provide the patient with } \\
\text { your initial opinion }\end{array}$ \\
\hline $\begin{array}{l}\text { Discuss next } \\
\text { steps }\end{array}$ & $\begin{array}{l}\text { This could include a discussion with your } \\
\text { supervising physician in the future to set up a } \\
\text { follow-up appointment. }\end{array}$ \\
\hline
\end{tabular}

Not only the doctor should be able to speak effectively, he must listen to the other person's words and engage in communication on what the other person is speaking about.

Get feedback from the patient to ensure that he was properly understood the conversation/instructions. ${ }^{7}$

\section{Conclusion}

Good doctor patient communication is important and has multiple impacts on various aspects of health outcomes. The impacts included better health outcomes, higher compliance to therapeutic regimens in patients, higher patient and clinician satisfaction and a decrease in malpractice risk. Conducting research in this area may help clinicians, educators and health service administrators to better understand the doctor patient relationship and doctor patient communication that is unique in our culture and social settings. This will provide a framework and foundation from which further studies on effective intervention that aims to improve doctor patient relationship can be conducted.

\section{References}

1. Gordon G. H., Whelan G., et al. Assessing competence in communication and interpersonal skills: the Kalamazoo II report. Acad Med. 2004;79((6)):495-507)

2. Tongue J R., Epps H. R., Forese L. L. Communication skills for patient-centered care: research-based, easily learned techniques for medical interviews that benefit orthopaedic surgeons and their patients. J Bone Joint Surg Am. 2005;87:652-658.)

3. Grembowski D, Paschane D, Diehr P, Katon W, Martin D, Patrick D, Managed care, physician job satisfaction, and the quality of primary care. J Gen InternMed 2005; 20: 271-277.

4. Jackson JL, Chamberlin J, Kroenke K. Predictors of patient satisfaction. Social Science andMedicne 2001; 52: 609-20.

5. Cegala DJ, Marinelli T, Post D. The effects of patient communication skills training on compliance. Archives of Family Medicine 2000; 9: 57-64

6. Arora N. Interacting with cancer patients: the significance of physicians' communication behavior. Soc Sci Med. 2003;57((5)):791-806. [PubMed]

7. Yasmeen BH N. editorial . Communication : A Basic skill of Medical Practice. NIMCJ 2013; 5(1) 291-292. 